\title{
Antibacterial Activity of Hydrophobic Composite Materials Containing a Visible-Light-Sensitive Photocatalyst
}

\author{
Kentaro Yamauchi, ${ }^{1}$ Yanyan Yao, ${ }^{2,3}$ Tsuyoshi Ochiai, ${ }^{2,4}$ Munetoshi Sakai, ${ }^{2}$ \\ Yoshinobu Kubota, ${ }^{3}$ and Goro Yamauchi ${ }^{5}$ \\ ${ }^{1}$ Collaborative Research Center, Daido University, 10-3 Takiharu-cho, Minami-ku, Nagoya 457-8530, Japan \\ ${ }^{2}$ Kanagawa Academy of Science and Technology, 3-2-1 Sakado, Takatsu-ku, Kawasaki-shi, \\ Kanagawa 213-0012, Japan \\ ${ }^{3}$ Department of Urology and Molecular Science, Graduate School of Medicine, Yokohama City University 3-9 Fukuura, \\ Kanazawa-ku, Yokohama 236-004, Japan \\ ${ }^{4}$ Division of Photocatalyst for Energy and Environment, Research Institute for Science and Technology, Tokyo University of Science, \\ 1-3 Kagurazaka, Shinjuku-ku, Tokyo 162-8601, Japan \\ ${ }^{5}$ Department of Information Design, Daido University, 10-3 Takiharu-cho, Minami-ku, Nagoya 457-8530, Japan
}

Correspondence should be addressed to Goro Yamauchi, gyamauch@daido-it.ac.jp

Received 15 March 2011; Revised 25 August 2011; Accepted 7 September 2011

Academic Editor: J. Anthony Byrne

Copyright ( $\odot 2011$ Kentaro Yamauchi et al. This is an open access article distributed under the Creative Commons Attribution License, which permits unrestricted use, distribution, and reproduction in any medium, provided the original work is properly cited.

\begin{abstract}
The conventional superhydrophobic surface offered by PTFE provides no sterilization performance and is not sufficiently repellent against organic liquids. These limit PTFE's application in the field of disinfection and result a lack of durability. $\mathrm{N}$-doped TiO $\mathrm{C}_{2}$ photocatalyst added PTFE composite material was developed to remedy these shortcomings. This paper reports the surface characteristics, and the bactericidal and self-cleaning performance of the newly-developed composite material. The material exhibited a contact angle exceeding 150 degrees consistent with its hydrophobicity despite the inclusion of the hydrophilic Ndoped $\mathrm{TiO}_{2}$. The surface free energy obtained for this composite was $5.8 \mathrm{mN} / \mathrm{m}$. Even when exposed to a weak fluorescent light intensity $(100 \mathrm{~lx})$ for 24 hours, the viable cells of gram-negative E. coli on the $12 \% \mathrm{~N}$-doped $\mathrm{TiO}_{2}-\mathrm{PTFE}$ film were reduced 5 logs. The higher bactericidal activity was also confirmed on the gram-positive MRSA. Compared with the N-doped $\mathrm{TiO}_{2}$ coating only, the inactivation rate of the composite material was significantly enhanced. Utilizing the $\mathrm{N}$-doped $\mathrm{TiO}_{2}$ with the PTFE composite coating could successfully remove, by UV illumination, oleic acid adsorbed on its surface. These results demonstrate the potential applicability of the novel $\mathrm{N}$-doped $\mathrm{TiO}_{2}$ photocatalyst hydrophobic composite material for both indoor antibacterial action and outdoor contamination prevention.
\end{abstract}

\section{Introduction}

It is well known that the conventional superhydrophobic surface offered by polytetrafluoroethylene (PTFE) provides no sterilization performance and is not sufficiently repellent against organic matters. Thus, there is potential risk for bacteria to adhere to its surface more readily in ambient air, as well as organic matters is considered to reduce the durability of the superhydrophobic performance. To remedy this shortcoming, anatase titanium dioxide $\left(\mathrm{TiO}_{2}\right)$, a UV light-sensitive photocatalyst added water repellent composite material has been developed in our previous study $[1-5] . \quad \mathrm{TiO}_{2}$ was used to demonstrate the inactivation of various bacteria, such as Escherichia coli (E. coli), methicillin-resistant Staphylococcus aureus (MRSA), Pseudomonas aeruginosa (P. aeruginosa), Legionella pneumophila (L. pneumophila) [6-8], and Clostridium difficile spores [8]. The inclusion of $\mathrm{TiO}_{2}$ to the PTFE coating is expected to generate antimicrobial and self-cleaning properties, which would expand its scope of application. Anatase $\mathrm{TiO}_{2}$-added PTFE composite material is not only water-repellent but also exhibits self-cleaning properties. However, because anatase 
$\mathrm{TiO}_{2}$ is catalytically active only under ultraviolet irradiation, its application is limited to outdoor usage [9-12].

In recent years, nosocomial infections have become a very important issue, with the appearance of resistant bacteria and have thus attracted much great attention [13]. Improving the hospital environment is recognized as a highly effective countermeasure to combat this problem. In response to the problem, we have developed a hydrophobic, self-cleaning composite material by adding $\mathrm{N}$-doped $\mathrm{TiO}_{2}$, a visible-light-sensitive photocatalyst [14], to a hydrophobic composite material containing dispersed PTFE particles in order to obtain antibacterial properties. This novel coating is expected to be useful in both as exterior or interior wall coating. The surface characteristics of the newly developed composite are examined in this paper. Furthermore, the antibacterial activities of the developed composite against $E$. coli and MRSA were evaluated under visible-light irradiation with intensities ranging from 100 to $2.000 \mathrm{~lx}$, which is equivalent to indoor and outdoor conditions.

\section{Materials and Methods}

2.1. Development of Hydrophobic Composite Material. The samples were composed of commercial PTFE particles, a fluorinated binder, and fluoro oil with varying amounts of $\mathrm{N}$-doped $\mathrm{TiO}_{2}(0,3,8$, and $12 \mathrm{wt} \%)$. N-doped $\mathrm{TiO}_{2}$ was provided by courtesy of Sumitomo Chemical Co., Ltd. (Japan). The PTFE particles, fluorinated binder, fluoro oil and $\mathrm{N}$-doped $\mathrm{TiO}_{2}$ mixture was sprayed over a substrate, together with butyl acetate. A dispersed particulate composite material about $5 \mu \mathrm{m}$ in thickness was formed with a single spraying. Particulate composite materials about $15 \mu \mathrm{m}$ in thickness were formed by spraying the entire substrate three times. The composite material was ready for the various measurements 24 hours after the butyl acetate dried.

\subsection{Characteristics}

2.2.1. Surface Characteristics. Contact angles were measured with an automatic contact angle meter (CA-Z; Kyowa Interface Science Ltd., Saitama Japan). A drop of water was deposited on the sample using a syringe. The contact angle was measured after the tip of the needle was separated from the drop. The measured contact angles, therefore, were equilibrium contact angles and not advancing or receding contact angles. The contact angles were determined at five different positions for each sample.

The surface free energy of the sample was obtained by the following procedure. The contact angles $\theta_{S L}$ of $\alpha$ bromonaphthalene $\left(90^{\circ}\right)$, methylene iodide $\left(87^{\circ}\right)$, and water $\left(152^{\circ}\right)$ were substituted into the Young-Dupre equation:

$$
W_{\mathrm{SL}}=\gamma_{\mathrm{LV}}\left(1+\cos \theta_{\mathrm{SL}}\right) \text {, }
$$

where $W_{\mathrm{SL}}$ is the work of adhesion and $\gamma_{\mathrm{LV}}$ is the surface free energy of the liquid.

The dispersion, polar, and hydrogen-bonding components of $W_{\mathrm{SL}}$ provided the dispersion $\gamma_{\mathrm{SV}}^{d}$, polar $\gamma_{\mathrm{SV}}^{p}$, and hydrogen-bonding $\gamma_{\mathrm{SV}}^{h}$ components of the surface free energy using the Kitazaki-Hata method [15]. The surface free energy $\gamma_{\mathrm{SV}}$ of the sample was obtained via the following formula:

$$
\gamma_{\mathrm{SV}}=\gamma_{\mathrm{SV}}^{p}+\gamma_{\mathrm{SV}}^{h}+\gamma_{\mathrm{SV}}^{d}
$$

The samples were observed using a JSM-6300F scanning electron microscope. The transmittance IR spectrum of the PTFE powder was obtained using an MFT-2000 FT-IR spectrometer. Crushed potassium bromide ( $\mathrm{KBr})$ crystal and PTFE powders were mixed and pressed into a disk, which was then placed in the FT-IR spectrometer for measurement.

2.2.2. Antibacterial Testing. The bacterial activity of the PTFE composite against E. coli (NBRC 3972; Natinol Institute of Technology and Evaluation, Biological Resource Center, Japan) and MRSA (clinically isolated by the Graduate School of Medicine, Yokohama City University) was evaluated, after some adjustments, in accordance with Japanese Industrial Standard methods (JIS R 1702) [16]. The bacterial strains were cultured twice on nutrient agar plates (E-MC35, Eikenkizai, Japan) at $37^{\circ} \mathrm{C}$ for $16 \sim 24$ hours. The strains were then suspended in a $1 / 500$ nutrient broth (NB) solution (E-MC35, Eikenkizai, Japan) with a $\mathrm{pH}$ of 7.0, and diluted to approximately $10^{6}$ colony-forming units (CFUs) per milliliter to be utilized for bactericidal testing.

Before testing, all the water-repellent composite samples $(50 \times 50 \mathrm{~mm})$ were presterilized by UV light with an irradiance of $1 \mathrm{~mW} \cdot \mathrm{cm}^{-2}$ overnight. A sterilized moisturecontrol paper filter was placed in a sterilized Petri dish, $5 \mathrm{~mL}$ of sterilized distilled water was added, and then a glass tube was placed on the paper filter to avoid contact between the test material and the paper filter. The sterilized test material was then placed on the glass tube, and $100 \mu \mathrm{L}$ of the bacterial suspension (approximately $10^{5}$ CFUs) was deposited on the surface of the test material. Because the test surface is hydrophobic, a covering quartz glass plate $(40 \times 40 \mathrm{~mm})$ was applied to spread out the suspension drip. Then, another quartz glass plate $(100 \times 100 \mathrm{~mm})$ was placed on top of the Petri dish. The paper filter, distilled water, and quartz glasses plates were all employed to prevent the evaporation the test bacterial suspension (Figure 1). The Petri dishes containing the specimens were illuminated by $20 \mathrm{~W}$ tubular-type white fluorescent lamps (Hitachi FL20SSW/18-B; Tokyo, Japan) for 24 hours. The influence of the light intensity on the bactericidal activity was examined for 100, 300, and 2000 lx. Only the intensity of $2000 \mathrm{~lx}$ included light in the UV region with wavelengths less than $400 \mathrm{~nm}$ at an intensity of $0.01 \mathrm{~mW} \cdot \mathrm{cm}^{-2}$. The light intensity incident on the center of the specimen surface was adjusted by a UD-40 radiometer probe head (Topcon Corporation; Tokyo, Japan).

After illumination, the specimens were washed with $10 \mathrm{~mL}$ of soybean-casein digest broth including lecithin and polysorbate 80 (SCDLP) (Nihon Pharmaceutical co., LTD, Japan). The washing solution was diluted with phosphatebuffered saline (PBS) in a 10-fold dilution series. At each dilution stage, aliquots $(1 \mathrm{~mL})$ of the SCDLP solution were mixed with the nutrient agar medium $(14 \mathrm{~mL})$ (Becton Dickinson, Franklin Lakes, NJ) at $45^{\circ} \mathrm{C}$ in a $10 \mathrm{~cm}$ Petri dish 


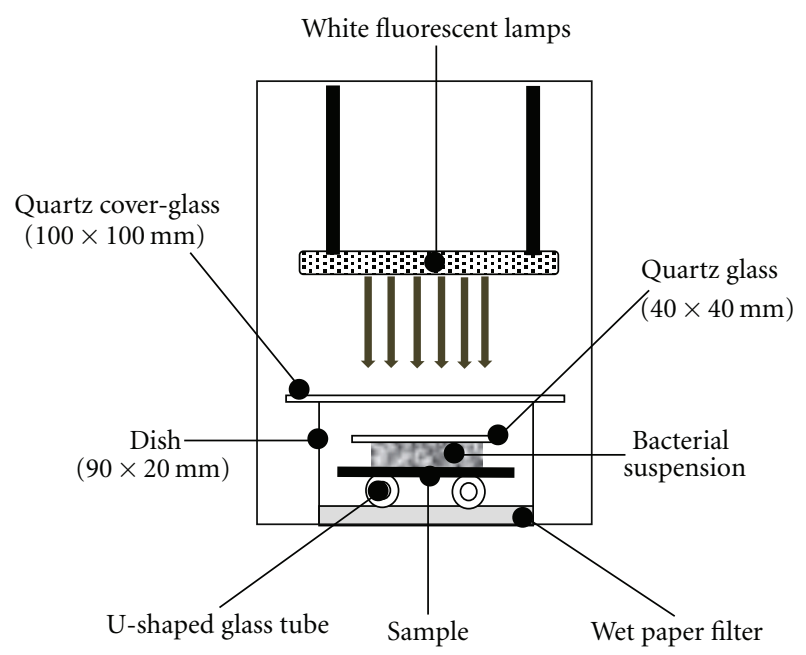

FIGURE 1: Schematic illustration of assessment method for investigating the bactericidal effect of PTFE hydrophobic composite films with and without the addition of $\mathrm{N}$-doped $\mathrm{TiO}_{2}$.

and allowed to cool to room temperature. After the medium solidified, the dishes were incubated at $35^{\circ} \mathrm{C}$ for 24 to 48 hours prior to determining the number of CFUs.

Bacterial tests were conducted by three parallel analyses for each sample, and the viable cells count was obtained from the average value of the product of the CFUs multiplied by the dilution rate and by ten as shown as follows:

$$
\text { Viable bacterial cells }=N \times \text { dilution rate } \times 10 \text {, }
$$

where $N$ is the number of CFUs on the $\mathrm{N}$-doped $\mathrm{TiO}_{2}$-PTFE composite films after visible-light illumination for a period of time. The value 10 indicates the sample washing solution (SCDLP liquid) volume.

When no CFUs were observed in undiluted SCDLP liquid, this indicated that the detection limit was no more than 10 CFUs. In such case, the viable cell count was expressed as " $\leq 10$ " to indicate the detection limit. The determination of the disinfectant property is given in terms of log decrease. $\mathrm{N}$-doped $\mathrm{TiO}_{2}$-free PTFE composite films were used as contrast samples.

\subsubsection{Assessment of Self-Cleaning Performance. To assess} the oxidative self-cleaning performance of the $\mathrm{N}$-doped $\mathrm{TiO}_{2}$-PTFE composite coatings, measurement of the contact angles of the composite coatings contaminated with oleic acid $\left(\mathrm{C}_{18} \mathrm{H}_{34} \mathrm{O}_{2}\right)$ during exposure to UV irradiation was performed according to the JIS R 1703-1 standard method [17]. The light source selected here is based on assumption that $\mathrm{N}$-doped $\mathrm{TiO}_{2}$-PTFE composite coating used outdoor is more susceptible to contamination by organic pollutants and sunlight including strong ultraviolet light. Prior to measuring the contact angles, the samples were cleaned for 24 hours by $2 \mathrm{~mW} \cdot \mathrm{cm}^{-1}$ of UV illumination incident on the testing surface to remove organic pollutants. Then, the samples were contaminated by dip coating $\left(60 \mathrm{~cm} \cdot \mathrm{min}^{-1}\right)$ with $0.5 \mathrm{vol} \%$ oleic acid diluted in $n$-heptane. After contamination, the
TABLE 1: Contact angles of water and surface free energy on the PTFE hydrophobic composite films with the addition of N-doped $\mathrm{TiO}_{2}$.

\begin{tabular}{lccc}
\hline & \multicolumn{1}{c}{$\begin{array}{c}\text { Contact } \\
\text { angle }(\text { degree })\end{array}$} & $\begin{array}{c}\text { Surface free } \\
\text { energy } \\
(\mathrm{mN} / \mathrm{m})\end{array}$ \\
\hline $\begin{array}{l}\text { Without } \\
\text { N-doped } \mathrm{TiO}_{2}\end{array}$ & $3 \mathrm{wt} \%$ & 152 & 5.8 \\
\hline With N-doped & $8 \mathrm{wt} \%$ & 151 & - \\
$\mathrm{TiO}_{2}$ & $12 \mathrm{wt} \%$ & 152 & 5.0 \\
\hline
\end{tabular}

samples were dried at $70^{\circ} \mathrm{C}$ for 15 minutes and were then irradiated for 230 hours using an unfiltered UV light source (Toshiba FL10BLB; Tokyo, Japan). The N-doped $\mathrm{TiO}_{2}$-free PTFE composite was again used for contrast testing.

\section{Results and Discussion}

\subsection{Surface Characteristics}

3.1.1. Contact Angles and Surface Free Energy. The results of water contact angles and surface free energy of the $\mathrm{N}$-doped $\mathrm{TiO}_{2}$-PTFE composite material are presented in Table 1.

All composite samples exhibited contact angles exceeding $150^{\circ}$, which is consistent with their hydrophobicity despite the presence of the hydrophilic $\mathrm{N}$-doped $\mathrm{TiO}_{2}$ photocatalyst. The contact angles of similar materials are usually expected to lie between those of PTFE and those of the binder with additives, including hydrophilic $\mathrm{N}$-doped $\mathrm{TiO}_{2}$. Instead, these angles $\left(150^{\circ}\right)$ were significantly greater than those of pure PTFE $\left(110^{\circ}\right)$. This is consistent with results previously reported by Yamauchi et al. [18]. In that study, a particulate composite model was analysed by the Wenzel equation, which takes into consideration surface roughness [19], and the Cassie equation, which considers heterogeneous surfaces [20]. They concluded that the binder wets more easily with water than the PTFE in PTFE particulate composite materials. In such a system, the contact angle increases with increasing PTFE concentration, however, and beyond the contact angle of the PTFE. When the concentration of PTFE particles dispersed in an appropriate binder reached $80 \mathrm{wt} \%$, more than $78 \%$ of the surface area between the water droplets and composite surface was covered by air due to the surface roughness of the PTFE. Thus, we consider that the same tendency may be observed in the $\mathrm{N}$-doped $\mathrm{TiO}_{2}$-PTFE composite materials if a part of the binder is replaced with Ndoped $\mathrm{TiO}_{2}$. Nakajima et al. [1] also reported a similar result; $\mathrm{TiO}_{2}$ nanoparticles added to superhydrophobic thin films, at a concentration below $20 \mathrm{wt} \%$, did not significantly increase the hydrophobicity of the films significantly even after UV illumination for 800 hours at an intensity of $1.7 \mathrm{~mW} \cdot \mathrm{cm}^{-2}$.

The surface free energy of the $8 \mathrm{wt} \% \mathrm{~N}$-doped $\mathrm{TiO}_{2}$ composite material was $5.8 \mathrm{mN} \cdot \mathrm{m}^{-1}$, similar to that of $\mathrm{CF}_{3}$ $\left(6 \mathrm{mN} \cdot \mathrm{m}^{-1}\right)$ [21]. This hydrophobicity reflects the low surface energy of the $\mathrm{N}$-doped $\mathrm{TiO}_{2}$-PTFE composite coating, which is expected to inhibit the adhesion of contaminants. 


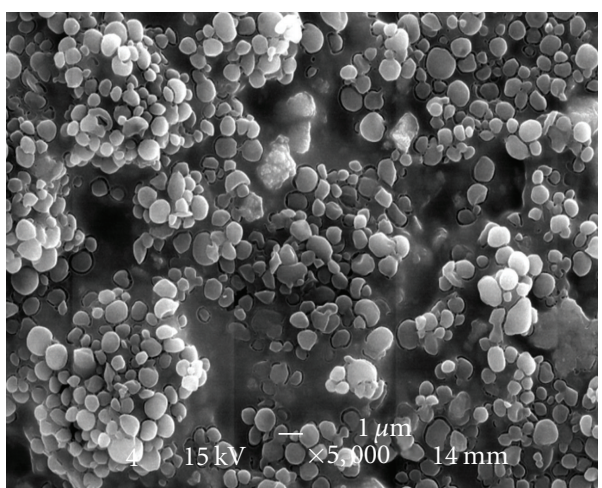

FIGURE 2: Scanning electron micrograph of the surface of a sample composed of $80 \mathrm{wt} \%$ PTFE, $8 \mathrm{wt} \% \mathrm{~N}$-doped $\mathrm{TiO}_{2}$, fluoro-oil and the remainder of fluorine binder. The water repellent property of the sample is attributed to the surface roughness created by the PTFE particles.

3.1.2. Scanning Electron Microscope Observation. A scanning electron micrograph of the sample containing $80 \mathrm{wt} \%$ PTFE and $8 \mathrm{wt} \% \mathrm{~N}$-doped $\mathrm{TiO}_{2}$ is shown in Figure 2. The micrograph reveals many small spherical aggregates of PTFE particles, indicating the heterogeneous morphology of the composite coating. Therefore, any analysis of surface wetting properties must consider the surface heterogeneity resulting from the PTFE particles and the binder. Such an analysis has previously been conducted by Yamauchi et al. [18]; they attributed the extraordinary hydrophobicity to the presence of air between the water droplets and the substrate surface.

\subsubsection{Fourier Transform Infrared Spectrometer Observation.} The Fourier Transform Infrared Spectrometer Observation (FT-IR) spectrum of the PTFE powder used for the samples is shown in Figure 3. The FT-IR spectra show clear peaks for the $\mathrm{CF}_{3}\left(1213 \mathrm{~cm}^{-1}\right)$ and $\mathrm{CF}_{2}$ (1155 and $639 \mathrm{~cm}^{-1}$ ) groups, which are responsible for the hydrophobicity of the composite material. No peak was observed for $\mathrm{C}=\mathrm{O}\left(1800 \mathrm{~cm}^{-1}\right)$ which causes the hydrophilic behaviour reported by Yamauchi et al. [4]. This finding accounts for the preventing of deterioration in the hydrophobicity of the composite material.

3.2. Bactericidal Properties. It is well known that superhydrophobicity is not sufficient to repel organic matter. Thus, there is potential for bacteria to adhere to the composite more readily in ambient air. The addition of $\mathrm{N}$-doped $\mathrm{TiO}_{2}$ to the PTFE coating was expected to generate antimicrobial properties, which would expand its scope of application. We analyzed the bactericidal properties of the $\mathrm{N}$-doped $\mathrm{TiO}_{2}$-PTFE composite by the test method described in Section 2.2.2 and shown in Figure 1.

Although the E. coli and MRSA cells had to be artificially attached to the surface of $\mathrm{N}$-doped $\mathrm{TiO}_{2}$-PTFE composite, the results revealed a very high level of bactericidal activity. Figure 4 shows the decrease in viable E. coli cells on the PTFE hydrophobic composite films with $\mathrm{N}$-doped $\mathrm{TiO}_{2}$. It can be seen in Figure 4 that under 1000 and $2000 \mathrm{~lx}$ visible-light

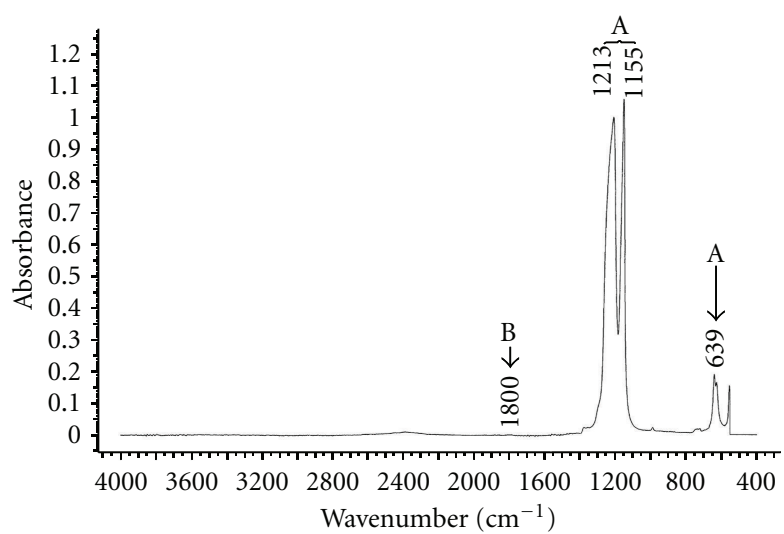

A: PTFE originated absorption peak

$\mathrm{B}: \mathrm{C}=\mathrm{O}$ originated absorption peak

Figure 3: FT-IR spectrum of PTFE powder. A denotes $\mathrm{CF}_{3}$ $\left(1213 \mathrm{~cm}^{-1}\right)$ and $\mathrm{CF}_{2}\left(1155 \mathrm{~cm}^{-1}, 639 \mathrm{~cm}^{-1}\right)$ adsorption peaks. $\mathrm{B}$ denotes the $\mathrm{C}=\mathrm{O}\left(1800 \mathrm{~cm}^{-1}\right)$ absorption peak.

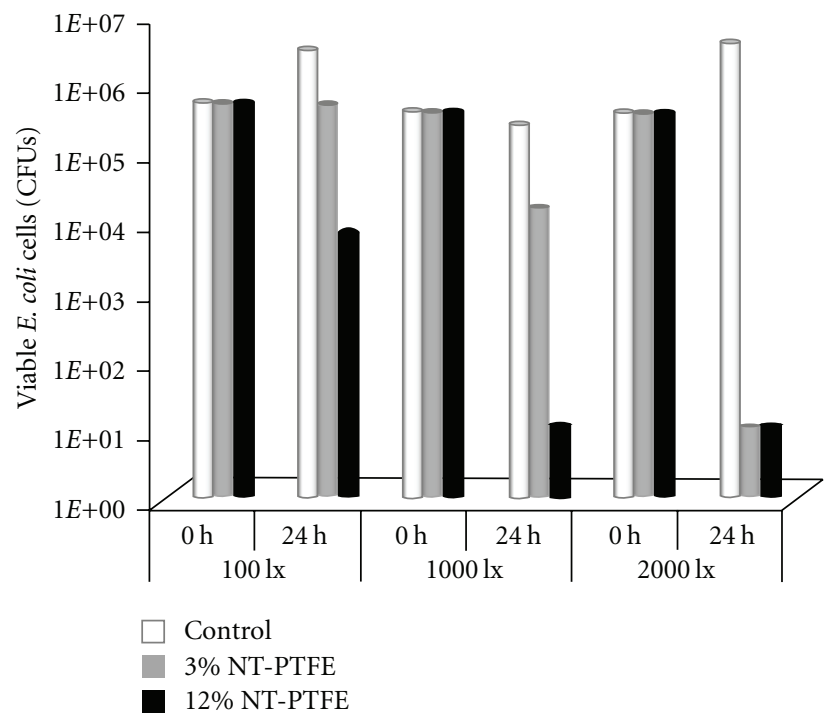

Figure 4: Antibacterial activity of PTFE hydrophobic composite films, without (Control) and with the addition of $\mathrm{N}$-doped $\mathrm{TiO}_{2}$ (NT-PTFE), on E. coli under visible-light illumination for 24 hours. The effects were dependant on visible-light intensity and the concentration of $\mathrm{N}$-doped $\mathrm{TiO}_{2}$.

illumination for $24 \mathrm{~h}$, the number of viable bacterial cells on the composite coating containing $12 \mathrm{wt} \%$ of $\mathrm{N}$-doped $\mathrm{TiO}_{2}$ decreased from $\sim 10^{5}$ CFUs to a value below the detection limits of the colony-formation method set at 10 CFUs. Also, even under very low-intensity illumination $(100 \mathrm{~lx})$, the number of viable $E$. coli cells decreased two logs (Figure 4). As shown in Figure 5, by using $2000 \mathrm{~lx}$ visible-light irradiation, the number of viable MRSA cells decreased from $\sim 10^{5}$ cells to less than 10 CFUs, for all samples containing differing amounts of $\mathrm{N}$-doped $\mathrm{TiO}_{2}$. It can be seen from Figures 4 and 5 that the bactericidal 


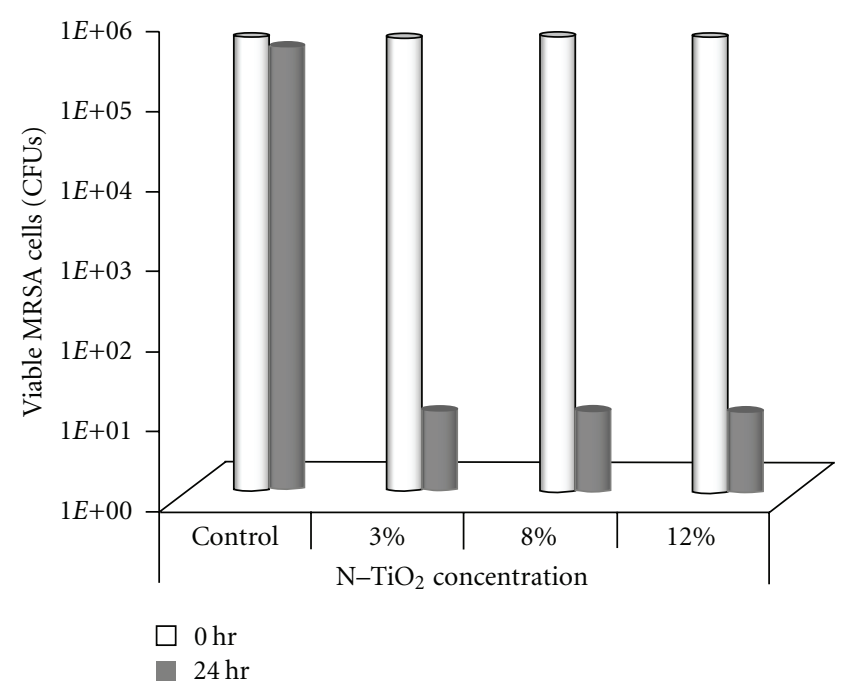

Figure 5: Antibacterial activity of PTFE hydrophobic composite films with N-doped $\mathrm{TiO}_{2}$ (NT) on MRSA under 2000 lx of visible light illumination for $24 \mathrm{~h}$. The PTFE hydrophobic without NT was used as control.

activity on E. coli is lower than that on MRSA, at the surface of $3 \mathrm{wt} \% \mathrm{~N}-\mathrm{TiO}_{2} /$ PTFE under $2000 \mathrm{~lx}$ of visible light for $24 \mathrm{~h}$. This is consistent with a normal understanding: that is, the photocatalytic killing effect on Gram-positive strain is faster than that on Gram-negative strain $[6,8]$.

The data shows a possible approach to lower the incidence of hospital-related bacterial infection, since MRSA is the major pathogenic organism and is frequently resistant to many other agents [22, 23]. As has been previously reported, the bactericidal activity of the $\mathrm{N}$-doped $\mathrm{TiO}_{2}-\mathrm{PTFE}$ composite was dependent on the intensity of the visible light and the proportion of $\mathrm{N}$-doped $\mathrm{TiO}_{2}$ (Figure 4). No bactericidal effect was observed in the control sample (PTFE only). These revealed that $\mathrm{N}$-doped $\mathrm{TiO}_{2}$ nanoparticles are unique materials that contribute to the bactericidal action of the composite material. Furthermore, compared with the $\mathrm{N}$-doped $\mathrm{TiO}_{2}$-only coating, the bactericidal activity of $\mathrm{N}$ doped $\mathrm{TiO}_{2}$-PTFE composite was enhanced (Figure 6).

Numerous studies have explained the mechanism of photocatalytic antimicrobial activity as the loss of cell membrane integrity caused by electrons/holes or by reactive oxygen species (ROS) [24-26]. In the present investigation, we deem that the greater surface roughness (Figure 3 ) offered by PTFE results in more air pockets that provide additional oxygen for the photocatalytic reaction, which in turn leads to further ROS generation.

We also examined the rapid adhesion of bacterial cells to the $8 \mathrm{wt} \% \mathrm{~N}$-doped $\mathrm{TiO}_{2}$-PTFE composite coating by rinsing the samples with a nitrate-broth (NB) liquid containing $E$. coli. When the sample was rinsed with $1 \mathrm{~mL}$ of NB liquid containing $10^{7} \sim 10^{8}$ CFUs of $E$. coli for 20 seconds, approximately $10^{3} \mathrm{CFUs}$ of $E$. coli cells adhered to the surface. However, when the same amount of $E$. coli suspended in $1 \mathrm{~mL}$ of phosphate saline buffer was used for contrast experiments,

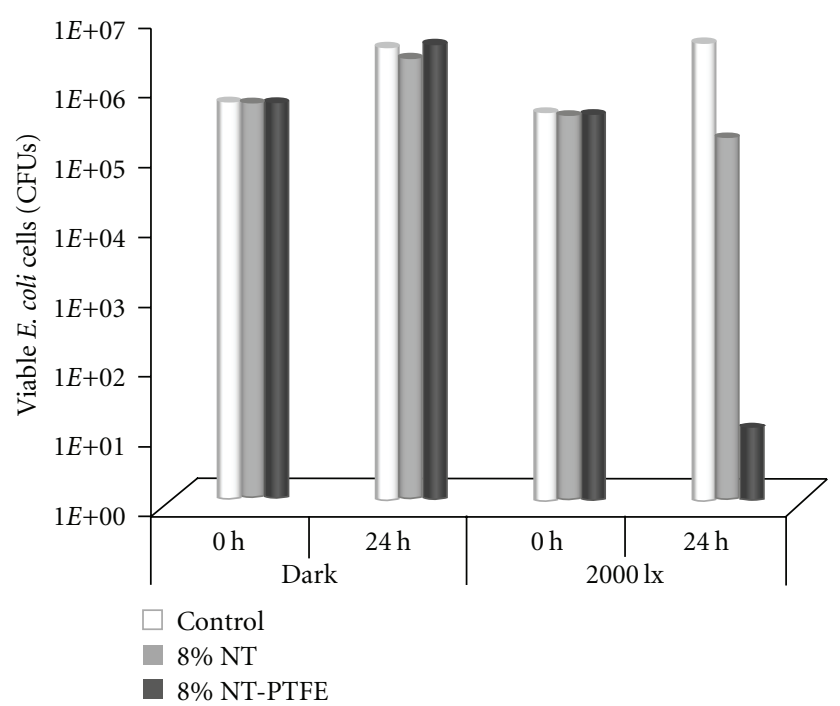

FIgURE 6: Enhancement of bactericidal activity by addition of Ndoped $\mathrm{TiO}_{2}$ to PTFE material, comparing with the $\mathrm{N}$-doped $\mathrm{TiO}_{2}$ alone coating. The $8 \% \mathrm{~N}$-doped $\mathrm{TiO}_{2}$-added PTFE film $(8 \% \mathrm{NT}$ PTFE) and $8 \% \mathrm{~N}$-doped $\mathrm{TiO}_{2}$ alone coating $(8 \% \mathrm{NT})$ were used in comparison tests.

TABLE 2: Adhesion of E. coli onto the PTFE hydrophobic composite films with and without the addition of $\mathrm{N}$-doped $\mathrm{TiO}_{2}(\mathrm{NT})$.

\begin{tabular}{lccc}
\hline $\begin{array}{l}\text { Visible-light } \\
\text { illuminating time (h) }\end{array}$ & \multicolumn{3}{c}{ Viable E. coli count/cells } \\
& $\begin{array}{c}8 \% \mathrm{NT} \\
\text { (Visible } \\
\text { Cight) } \\
2000 \mathrm{Lx}\end{array}$ & $\begin{array}{c}8 \% \mathrm{NT} \\
(\text { Dark) }\end{array}$ \\
\hline 0 & $1 \cdot E+03$ & $1 \cdot E+02$ & $\mathrm{NT}$ \\
8 & $1 \cdot E+03$ & $1 \cdot E+01$ & $\mathrm{NT}$ \\
24 & $1 \cdot E+05$ & $0 \cdot E+00$ & $1 \cdot E+05$ \\
\hline
\end{tabular}

By rinsing the samples with nutrient broth solution containing $10^{8} \mathrm{CFU} / \mathrm{mL}$ of $E$. coli for $10 \mathrm{sec}, 10^{3} \mathrm{E}$. coli cells were adsorbed on the surface of PTFE hydrophobic composite films. The viable $E$. coli were all inactivated with visible-light illumination at $2000 \mathrm{~lx}$ for 24 hours.

only 100 CFUs of $E$. coli were detected on the rinsed sample. These results reveal that bacterial cells are more readily adsorbed onto superhydrophobicity surface contaminated with organic material. However, although a small amount of E. coli was found to be adsorbed onto the $\mathrm{N}$-doped $\mathrm{TiO}_{2}$ PTFE composite surface, the cells were inactivated by using 1000 lx of visible-light illumination, as expected (Table 2).

3.3. Self-Cleaning Properties. The results of oxidative degradation of the PTFE composite coating on oleic acid under visible light, with and without $\mathrm{N}$-doped $\mathrm{TiO}_{2}$, are shown in Figure 7. From the data, large decreases in the contact angles could be observed in the composites coating both with and without $\mathrm{N}$-doped $\mathrm{TiO}_{2}$ when they were contaminated with oleic acid. It is noteworthy that the oleic acid was only 


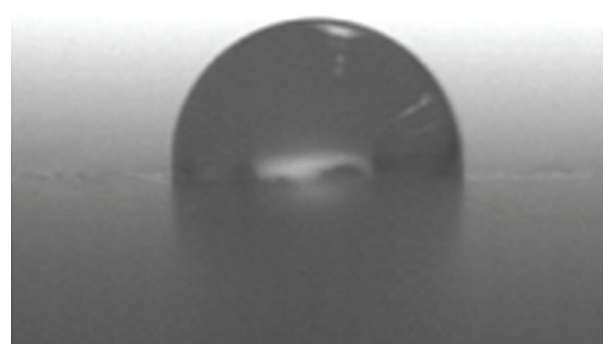

(a)

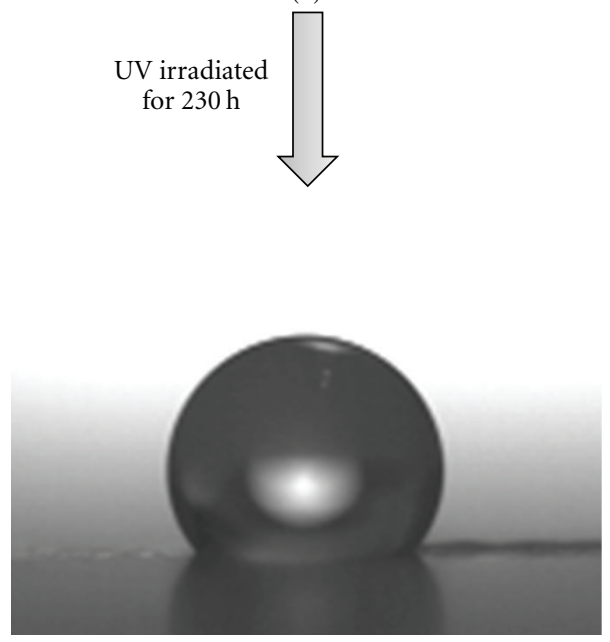

(b)

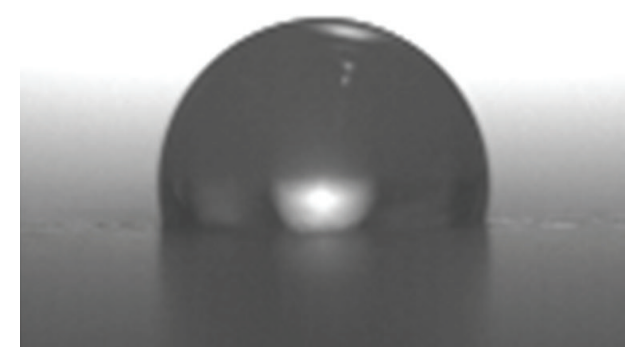

(c)

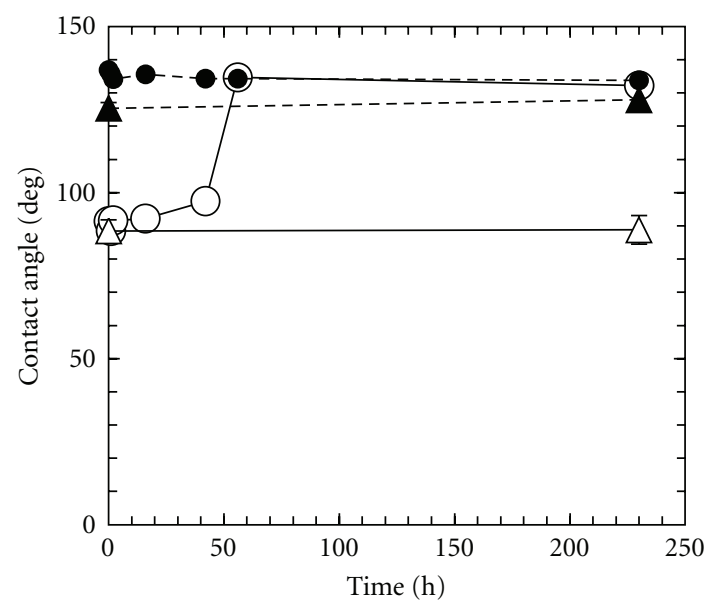

Figure 7: Recovery of water contact angles for $\mathrm{N}$-doped $\mathrm{TiO}_{2}-\mathrm{PTFE}$ hydrophobic composite coating contaminated with 0.5 vol. $\%$ oleic acid diluted in $n$-heptane, during exposure to $1 \mathrm{~mW} \cdot \mathrm{cm}^{-2}$ of UV-A light for 230 hours. A PTFE composite coating without the addition of $\mathrm{N}$-doped $\mathrm{TiO}_{2}$ was used as the control sample. (a) water droplet on the PTFE plus $12 \%$ NT surface without UV illumination. (b) water droplet on the PTFE plus 12\% NT after UV illumination. (c) water droplet on the control sample after UV illumination for 23 hours. Graph symbols represent @: PTFE plus $12 \%$ NT, Oleic acid (-); $\bigcirc$ : PTFE plus $12 \%$ NT, Oleic acid (+); $\boldsymbol{\Delta}$ : Control, Oleic acid (-); $\triangle$ : Control, Oleic acid (+).

removed successfully on the $\mathrm{N}$-doped $\mathrm{TiO}_{2}$-PTFE composite coating surface by $1 \mathrm{~mW} \cdot \mathrm{cm}^{-2}$ of UV irradiation for 230 hours, after which the contact angle recovered to its initial value. The mechanism of the photocatalytic degradation of oleic acid on $\mathrm{TiO}_{2}$ films has been analyzed by Rathouský et al. [27]. In their study, nonanal and 9-oxononanoic acid and azelaic and nonanoic acid were detected as primary and secondary intermediates, respectively. They proposed that oxidative degradation on the $\mathrm{TiO}_{2}$ film was induced by an attack of hydroxyl radials on the double bond. Eliminated hydroxyl radicals could act catalytically and thus accelerate the degradation of unsaturated compounds including fatty acids, which can be expected to be proportional to the degree of degradation (i.e., its transformation into more hydrophilic compounds, as well as into gaseous products such as $\mathrm{CO}_{2}$ and $\mathrm{H}_{2} \mathrm{O}$ ). These published propositions and our results clarify that, although the superhydrophobicity of such films is not sufficient to repel organic matter, especially oils, photocatalytic oxidization could eliminate these organic stains and preserve superhydrophobic surface after they have been exposed to outdoor conditions for a long period of time.

\section{Conclusion}

In this investigation, we developed a novel water-repellent and antimicrobial composite coating by combining an $\mathrm{N}$ doped $\mathrm{TiO}_{2}$ photocatalyst (a visible-light-sensitive photocatalyst) with polytetrafluoroethylene (PTFE) particles, a binder, and fluoro oil. This composite coating exhibited a water contact angle greater than 150 degrees, and a surface energy lower than $6 \mathrm{mN} / \mathrm{m}$, indicating superhydrophobicity. The composite coating also exhibited a high level of bactericidal activity against $E$. coli and MRSA by visible-light illumination at both high and low intensity. In particular, great than four logs of inactivation was observed on MRSA, which indicates that this newly developed superhydrophobic composite material may be resistant to the bacteria that cause nosocomial infections. Additionally, bacterial inactivation was enhanced, and a comparison with the $\mathrm{N}$-doped $\mathrm{TiO}_{2}-$ only coating revealed that this enhancement was attributed to the surface roughness offered by the PTFE; more air pockets provided additional oxygen for the photocatalytic reaction leading to greater reactive oxygen species generation. 
We also confirmed that organic stains adsorbed on the composite surface could be successfully removed utilizing photocatalytic oxidation, which resulted in sustainable high hydrophilic states. These results demonstrate potential applications of the new $\mathrm{N}$-doped $\mathrm{TiO}_{2}$ photocatalyst hydrophobic composite material not only for antibacterial action indoor, but also to prevent contamination outdoors.

\section{Acknowledgments}

This work was supported by Seeds Development Grant 08107 from the Japan Science and Technology Agency. The authors gratefully acknowledge the help of Konosuke Ikeda and Takashi Shimizu of NTT Advanced Technology Corporation for sample preparation. Kentaro Yamauchi, Yanyan Yao, and Goro Yamauchi contributed equally to this work.

\section{References}

[1] G. Yamauchu, K. Takai, and H. Saito, "PTEE based water repellent coating for telecommunication antennas," IEICE Transactions on Electronics, vol. E83-C, no. 7, pp. 1139-1141, 2000.

[2] H. Saito, K. Takai, and G. Yamauchi, "Water- and ice-repellent coatings," Surface Coatings International, vol. 80, no. 4, pp. 168-171, 1997.

[3] G. Yamauchi, J. D. Miller, H. Saito et al., "Wetting characteristics of newly developed water-repellent material," Colloids and Surfaces A, vol. 116, no. 1-2, pp. 125-134, 1996.

[4] G. Yamauchi, J. D. Miller, H. Saito et al., "Wetting characteristics of newly developed water-repellent material," in Proceedings of the 69th Colloid and Surface Science Symposium, pp. 125-134, Salt Lake City, Utah, USA, 1995.

[5] A. Nakajima, K. Hashimoto, T. Watanabe, K. Takai, G. Yamauchi, and A. Fujishima, "Transparent superhydrophobic thin films with self-cleaning properties," Langmuir, vol. 16, no. 17, pp. 7044-7047, 2000.

[6] Y. Yao, Y. Ohko, Y. Sekiguchi, A. Fujishima, and Y. Kubota, "Self-sterilization using silicone catheters coated with Ag and $\mathrm{TiO}_{2}$ nanocomposite thin film," Journal of Biomedical Materials Research-Part B Applied Biomaterials, vol. 85, no. 2, pp. 453-460, 2008.

[7] Y. Yao, T. Ochiai, H. Ishiguro, R. Nakano, and Y. Kubota, "Antibacterial performance of a novel photocatalytic-coated cordierite foam for use in air cleaners," Applied Catalysis B: Environmental, vol. 106, no. 3-4, pp. 592-599, 2011.

[8] P. S. M. Dunlop, C. P. Sheeran, J. A. Byrne, M. A. S. McMahon, M. A. Boyle, and K. G. McGuigan, "Inactivation of clinically relevant pathogens by photocatalytic coatings," Journal of Photochemistry and Photobiology A: Chemistry, vol. 216, no. 2-4, pp. 303-310, 2010.

[9] K. Takai, H. Saito, and G. Yamauchi, Composite International Community for Composite, Banff, 1997.

[10] G. Yamauchi, H. Saito, and K. Takai, "Surface characterization of a new water repellent coating material," in Proceedings of the International Conference on Surface Characterization of Adsorption \& Interfacial Reaction, p. 121, Cona, Hawaii, USA, 1998.

[11] G. Yamauchi, Y. Riko, Y. Yasuno, T. Shimizu, and N. Funakoshi, "Water-repellent coating for mobile phone microphones," in Proceedings of the Nano and Hybrid Coatings Conference, pp. 1-6, Manchester, UK, 2005.
[12] Y. Yasuno, Y. Riko, N. Funakoshi, T. Shimizu, and G. Yamauchi, "Environmentally robust electret condenser microphone," IEICE Transactions on Fundamentals of Electronics, Communications and Computer Sciences, vol. E89-A, no. 8, pp. 2226-2229, 2006.

[13] D. Gruson, G. Hilbert, F. Vargas et al., "Rotation and restricted use of antibiotics in a medical intensive care unit: impact on the incidence of ventilator-associated pneumonia caused by antibiotic-resistant gram-negative bacteria," American Journal of Respiratory and Critical Care Medicine, vol. 162, no. 3 I, pp. 837-843, 2000.

[14] R. Nakamura, T. Tanaka, and Y. Nakato, "Mechanism for visible light responses in anodic photocurrents at N-doped $\mathrm{TiO}_{2}$ film electrodes," Journal of Physical Chemistry B, vol. 108, no. 30, pp. 10617-10620, 2004.

[15] Y. Kitazaki and T. Hata, Japan Adhesion Society, vol. 8, 1972.

[16] H. Shima, Ed., "Fine ceramics (advanced ceramics, advanced technical ceramics) - Test method for antibacterial activity of photocatalytic products under photoirradiation and efficacy," JIS R 1702, Japanese Standards Association, Tokyo, Japan, 2006.

[17] "Fine ceramics (advanced ceramics, advanced technical ceramics)_-Test method for self-cleaning performance of photocatalytic materials-Part 1: measurement of water contact angle," JIS R 1703-1, Japanese Standards Association, Tokyo, Japan, 2007.

[18] G. Yamauchi, J. D. Miller, H. Saito, K. Takai, H. Takazawa, and T. Ueda, "The wetting characteristics of PTFE particulate composites," Materials Transactions, vol. 37, no. 4, pp. 721-728, 1996.

[19] R. N. Wentzel, "Resistance of solid surfaces to wetting by water," Industrial and Engineering Chemistry, vol. 28, pp. 988-994, 1936.

[20] A. B. D. Cassie, "Contact angles," Discussions of the Faraday Society, vol. 3, pp. 11-16, 1948.

[21] Y. Sakatani, Research Frontiers in Visible Light-Sensitive Photocatalysts, STS Ltd., Tokyo, Japan, 2002.

[22] J. D. Edgeworth, D. F. Treacher, and S. J. Eykyn, "A 25-year study of nosocomial bacteremia in an adult intensive care unit," Critical Care Medicine, vol. 27, no. 8, pp. 1648-1650, 1999.

[23] S. M. Smith, R. H.K. Eng, P. Bais, P. Fan-Havard, and F. Tecson-Tumang, "Epidemiology of ciprofloxacin resistance among patients with methicillin-resistant Staphylococcus aureus," Journal of Antimicrobial Chemotherapy, vol. 26, no. 4, pp. 567-572, 1990.

[24] E. C. Friedberg, G. C. Walker, and W. Siede, DNA Repair and Mutagenesis, ASM Press, Washington, DC, USA, 1995.

[25] G. Gogniat, M. Thyssen, M. Denis, C. Pulgarin, and S. Dukan, "The bactericidal effect of $\mathrm{TiO}_{2}$ photocatalysis involves adsorption onto catalyst and the loss of membrane integrity," FEMS Microbiology Letters, vol. 258, no. 1, pp. 18-24, 2006.

[26] P. C. Maness, S. Smolinski, D. M. Blake, Z. Huang, E. J. Wolfrum, and W. A. Jacoby, "Bactericidal activity of photocatalytic $\mathrm{TiO}_{2}$ reaction: toward an understanding of its killing mechanism," Applied and Environmental Microbiology, vol. 65, no. 9, pp. 4094-4098, 1999.

[27] J. Rathouský, V. Kalousek, M. Kolář, J. Jirkovský, and P. Barták, "A study into the self-cleaning surface properties-the photocatalytic decomposition of oleic acid," Catalysis Today, vol. 161, no. 1, pp. 202-208, 2011. 

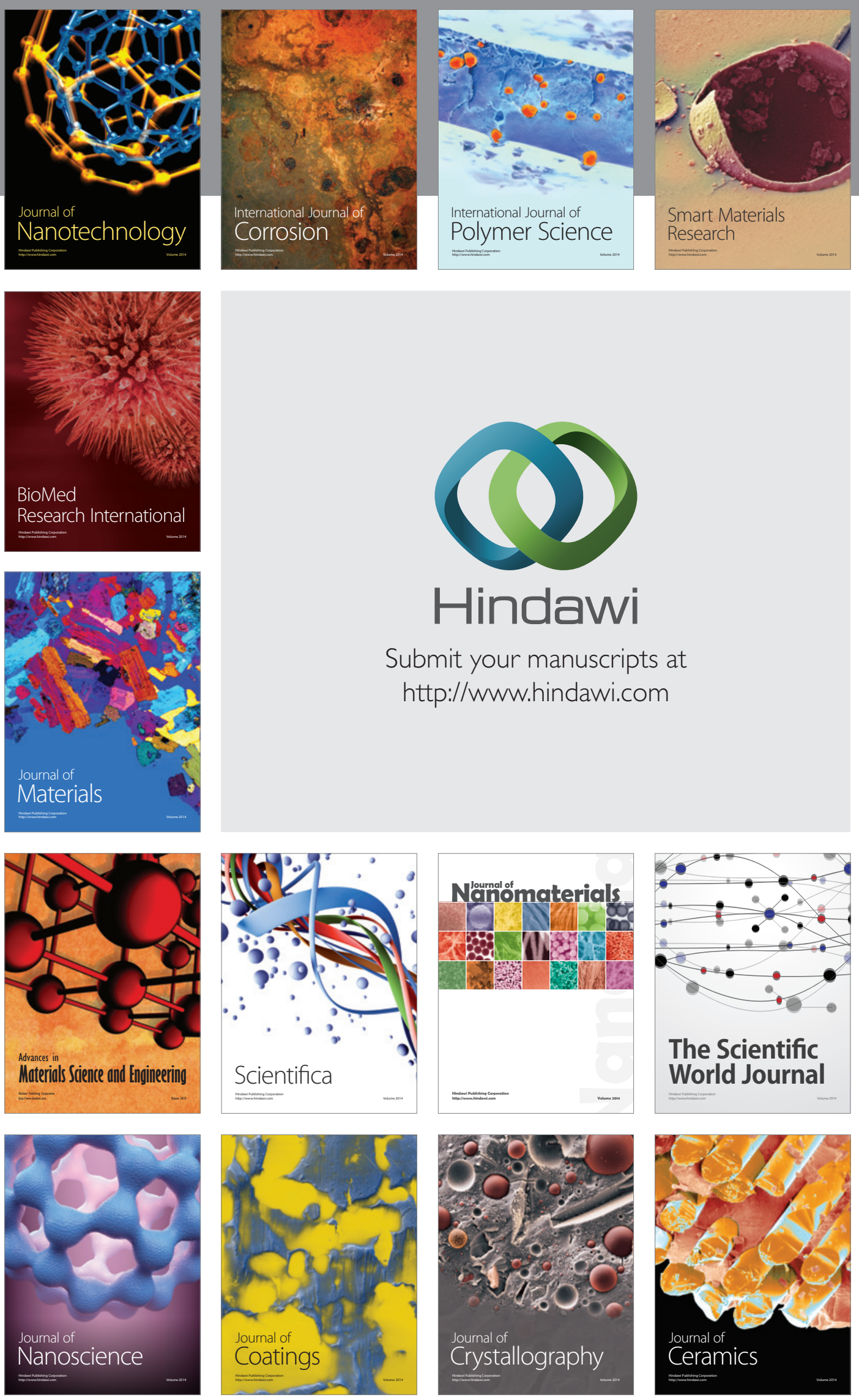

The Scientific World Journal

Submit your manuscripts at

http://www.hindawi.com

\section{World Journal}

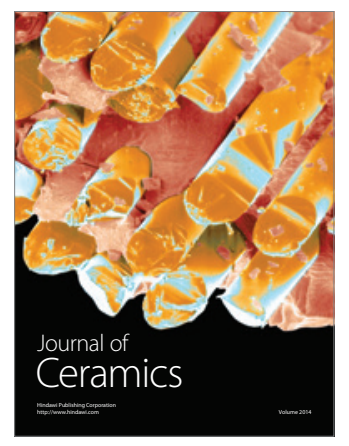

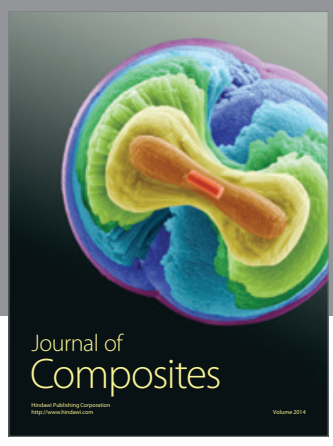
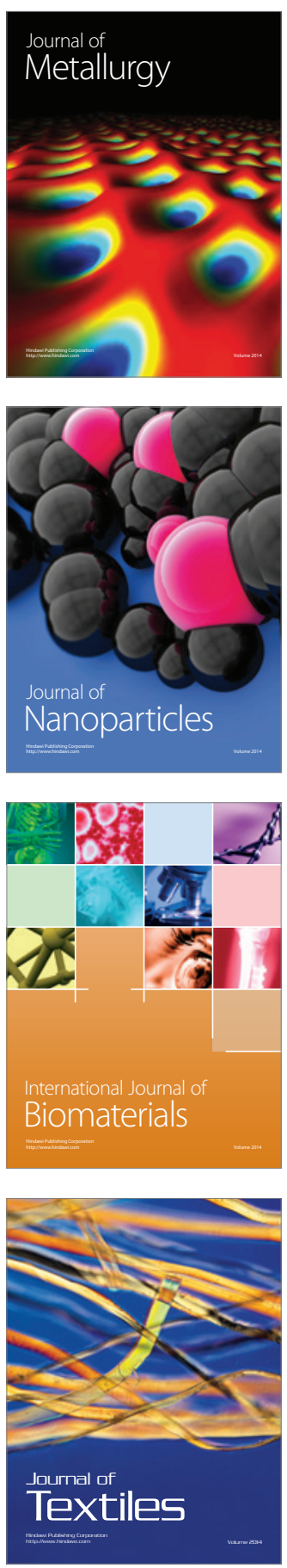